\title{
Responses and screening of white jute (Corchorus capsularis L.) genotypes against salinity stresses
}

\author{
Sadia Afrin Jui ${ }^{1}$, Md. Mia Mukul ${ }^{1 *}$, Md. Harun Or Rashid ${ }^{1}$, Iffat Jahan Nur ${ }^{1}$, Ranjit Kumar Ghosh ${ }^{1}$, \\ Md. Golam Mostofa ${ }^{1}$, Nargis Akter ${ }^{1}$, Md. Tipu Sultan ${ }^{2}$
}

${ }^{1}$ Breeding Division, Bangladesh Jute Research Institute (BJRI), Manik Mia Avenue, Dhaka, Bangladesh

${ }^{2}$ Jute Research Regional Sub-Station, BJRI, Pakhimara, Patuakhali, Bangladesh

*Email: mukul@bjri.gov.bd

\section{ARTICLE HISTORY}

Received: 03 January 2021

Accepted: 12 March 2021

Published: 01 May 2021

\section{KEYWORDS}

Jute breeding; Corchorus capsularis; Genotype; Salinity Tolerance; Soil salinity

\section{Abbreviation}

$\mathrm{BJC}=$ Bangladeshi Jute of Corchorus capsularis

BJRI= Bangladesh Jute Research Institute

$\mathrm{dS} / \mathrm{m}=$ Desi-siemens per meter $\mathrm{GDP}=$ Gross Domestic Product SRDI= Soil Resource Development Institute

\begin{abstract}
Soil salinity, a serious threat to jute cultivation in saline areas (southern parts) of Bangladesh. Bangladesh Jute Research Institute (BJRI) has developed a moderately salt tolerant White Jute variety (BJRI Deshi pat-8; BJC 2197) in 2013 which can't grow well in saline areas having more than $8.0 \mathrm{dSm}^{-1}$ salinity stress. Hence, 23 whitejute accessions and one control variety (BJC 2197) were tested to isolate the salt tolerant accession(s) for hybridization purpose followed by augmented design in farmers' field having nearly 8.0-9.0 dSm ${ }^{-1}$ salinity at Patuakhali district during mid-March to mid-August 2019. The experimental plot size was $3.0 \mathrm{~m}^{2}(3 \mathrm{~m} \times 1 \mathrm{~m})$ for each genotype having 3 lines of $1.0 \mathrm{~m}$ length, plantplant: $10-15 \mathrm{~cm}$ and line- line: $30 \mathrm{~cm}$ distance. Soil salinity was recorded during sowing, vegetative and plant maturity stages. In this study, the highest plant height $2.84 \mathrm{~m}$ was recorded in Acc. 2750 followed by Acc. $2589(2.76 \mathrm{~m})$ and Acc. $1779(2.69 \mathrm{~m})$. The highest fiber yield $\left(9.0 \mathrm{~g} \mathrm{plant}^{-1}\right)$ was observed in Acc. 1779 followed by Acc. 2589 (8.40 g plant $^{-1}$ ) and Acc. 2750 (8.0 g plant $\left.^{-1}\right)$. The lowest plant mortality rate (2.5\%) was found in Acc. 2750 followed by Acc.1779 (6.24\%), Acc. 1780 (7.50), Acc. 3556 (11.10\%), Acc. 2589 (11.20\%) and BJC 2197 (16.5\%). Few seeds were germinated in Acc. 3020 and Acc. 3658 but plants were died after 20 days of sowing. Six genotypes of cluster I showed higher diversity in Euclidean cluster analysis. The Acc. 2750, Acc. 1779, Acc. 2589 of cluster I having relative salinity tolerance and good fiber yield capacity would be grown in next year for confirmation as well as hybridization with the existing salinity susceptible variety to develop high yielding white jute variety for saline areas.
\end{abstract}

\section{Introduction}

Among the most important fibrous plants, Jute is second only to cotton in world's production of textile fibers (1). Chromosome number of jute is $2 n=2 x=14$ and it belongs to the genus: Corchorus, which is under the family: Tiliaceae (2). The genus comprises more than 170 species with $C$. olitorius $\mathrm{L}$. and $C$. capsularis L. as commercially cultivated species (3). Among which, C. olitorius L. along with most of Corchorus species considered to have originated along equatorial regions of East Africa and subsequently domesticated in India as fibre crop $(4,5)$. However, another cultivated species (C. capsularis L.) supposed to have originated and domesticated in South China and Indo Burma regions $(6,7)$. They are distributed throughout the tropical and sub-tropical regions of the world, particularly in Asia, Africa and Latin America $(6,8)$. For broadening the genetic base of new cultivars, genetic improvement of the cultivars of jute $(C$. olitorius $\mathrm{L}$. and $C$. capsularis $\mathrm{L}$.) is necessary $(9,10)$. These two jute species indeed more or less related with each other for the morphological characters but their maternal origins are different and incompatibility lies between them in respect of inter species hybridization $(5,11)$. On the contrary, the genetic variability present at the intraspecific level is low (12).

Soil salinity is a major abiotic stress and challenge for agricultural crop production which adversely affects crop production in arid and semi-arid lands in

(C) Jui et al (2021). This is an open-access article distributed under the terms of the Creative Commons Attribution License, which permits unrestricted use, distribution and reproduction in any medium, provided the original author and source are credited (https://creativecommons.org/licenses/by/4.0/)

To cite this article: Jui S A, Mukul M M, Rashid M H O, Nur I J, Ghosh R K, Mostofa M G, Akter N, Sultan M T. Responses and screening of white jute (Corchorus capsularis L.) genotypes against salinity stresses. Plant Science Today. 2021;8(2):416-424. https://doi.org/10.14719/pst.2021.8.2.1083 
the worldwide and Bangladesh is no exception under this impediment (13). Evaluation of jute genotypes for salt tolerance is highly important because of salt affected areas are constantly increasing worldwide especially in Bangladesh where salt tolerant jute variety is unavailable (14).

It is a major abiotic stress and challenge for agricultural crop production which adversely affects crop production in arid and semi-arid lands in the worldwide and Bangladesh is no exception under this impediment (13). According to one study (15), salinity stress has inhibitory effect on both seed germination and seedling growth of tossa jute and the jute varieties differed significantly in their tolerance to this salinity stress. Seed germination and seedling growth of tossa jute variety were completely inhibited at $300 \mathrm{mM} \mathrm{NaCl}$ at artificial environment.

According to one study (16), the Kalapara coastal belt is one of the nearest areas to the Bay of Bengal in Bangladesh. The greatest sources of saline water is the Bay of Bengal. The deficiencies micronutrients are common in saline soil. In the coastal region, the reduction of food crop production has significant impact on the national economy of Bangladesh (17). The salt stress is varied due to the reduction of fresh water flow from upstream tidal flow and groundwater discharge (18). The saline affected coastal areas of Bangladesh cover $32 \%$ of the country consisting of 19 districts and accommodate more than 35 million people (19). Increased salinization of arable land is expected to have devastating global effects, with prediction of $30 \%$ land loss within the next 25 years, and up to $50 \%$ by 2050 (13). About $70 \%$ of cultivable land of Bangladesh suffered from different degrees of salinity $(16,17)$. Salinity levels of Bangladesh vary in different months of the year. In the months of March-April, the peak dry season, maximum salinity occurs and minimum in the months of July-August after the onset of monsoon rain (20). Soil salinity causes physiological disorder in uptake and recycling of nutrients within the plant biological systems (21). In Bangladesh, about $1.51 \mathrm{~m}$ ha of arable lands are affected by varying degrees of salinity which adversely impairs crop ecosystem (22). Salinity is one of the major problems in the coastal region of Bangladesh that contributes to $20 \%$ of the total land area. About $53 \%$ of the coastal region is affected by different degrees of salinity (23). During 1973, salinity affected 83.3 million hectares of land; this was increased to 102 million hectares by 2000 . After that, salinity affected a recorded 105.6 million hectares during 2009 (22). Among these affected areas, around 2.5 million hectares of low-lying coastal lands represents 0.9 to 2.1 salinity level (SL) in Bangladesh $(17,24)$. Over the last 35 years, salinity has increased around $26 \%$ in the coastal region of Bangladesh (25).

At present, due to population density and increasing land salinization problems, breeding for salinity tolerance in many crops needs to be paid more attention. So, cultivation of jute is regularly being pressed to the marginal lands with higher grades of soil salinity year round (26). Bangladesh, the second largest producer of jute, produces the best quality jute in the world and leads the export market
(27). In addition, this crop is particularly important in Bangladesh where many small families depend on the income from growing and selling jute (28). Recently it was reported that the jute can grow readily in saline soils. Considering its tolerance especially to the chlorine salinity, jute has been recently suggested as a promising candidate for planting in wet lands and saline soils (28). Different jute genotypes would possess different tolerances to salinity, so it is necessary to screen out high salt tolerant jute genotypes for utilization in coastal region. Screening and identifying genotypes that maintain productivity under saline conditions is an effective approach (29).

Jute is an important bast fibre producing cash crop (30). Jute is the source of highly versatile environment friendly natural fibre. Bangladesh is the second largest jute producing country in the world and it earns a remarkable amount of foreign currency annually by exporting jute products (31). The contribution of jute is about $4 \%$ in GDP and earns about $5 \%$ of foreign exchange in 2019 (32-34). Multivariate method such as cluster analysis has proven to be useful for characterizing, evaluating and classifying germplasm for diversity when a large number of accessions or genotypes to be assessed for several characteristics of morphological and genetical importance $(35,36)$. Salt tolerant jute can grow readily in saline soils $(26,37)$. Screening for salt tolerance under field conditions is often not feasible due to the heterogeneous nature of field soil and seasonal fluctuations in rainfall (38).

Salt tolerant white jute variety should be developed for utilizing the saline areas of Bangladesh. But there is no sufficient information on salt tolerance of jute crop in Bangladesh (39).

Therefore, the present study was conducted to screen out the salinity tolerant white jute genotype(s) which will be used as breeding materials (parent) for developing high yielding salinity tolerant white jute variety.

\section{Materials and Methods}

\section{Location of the experiment}

The salinity affected areas are located in the southern belt of Bangladesh like Satkhira, Khulna and Patuakhali Districts (16). The experiment was conducted in farmer's field of saline zone at Kalapara of Patuakhali District (2156'59.8"N 90¹0'37.3"E) of Bangladesh during 15 March-15 August, 2019.

\section{Plant materials}

Twenty-four White Jute genotypes including one moderately salt (8.0-9.0 dSm$\left.{ }^{-1}\right)$ tolerant variety named BJRI Deshi Pat-8 (BJC 2197) were used in this study (Table 1). Seed materials were collected from the Gene Bank and Breeding Division of Bangladesh Jute Research Institute.

\section{Experimental design}

Twenty three new accessions and a moderately salt tolerant variety (control) of white jute were investigated for salinity tolerance in this study. An 
Table 1. Experimental plant materials with source of collection

\begin{tabular}{|c|c|c|c|c|c|c|c|c|}
\hline SL. No. & $\begin{array}{c}\text { Accession/ } \\
\text { Genotype }\end{array}$ & $\begin{array}{l}\text { Source of } \\
\text { collection }\end{array}$ & SL. No. & $\begin{array}{c}\text { Accession/ } \\
\text { Genotype }\end{array}$ & $\begin{array}{l}\text { Source of } \\
\text { collection }\end{array}$ & SL. No. & Accession/Genotype & $\begin{array}{l}\text { Source of } \\
\text { collection }\end{array}$ \\
\hline 1 & Acc-1779 & \multirow{8}{*}{ 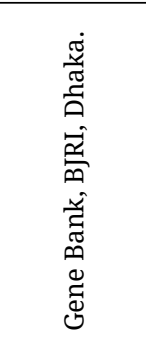 } & 9 & Acc-2759 & \multirow{8}{*}{ 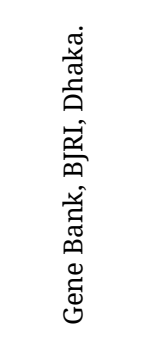 } & 17 & Acc-3596 & \multirow{7}{*}{ 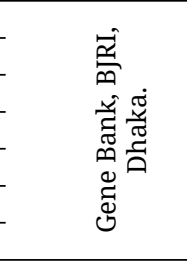 } \\
\hline 2 & Acc-1780 & & 10 & Acc-2999 & & 18 & Acc-3654 & \\
\hline 3 & Acc-1781 & & 11 & Acc-3015 & & 19 & Acc-3658 & \\
\hline 4 & Acc-2589 & & 12 & Acc-3017 & & 20 & Acc-3662 & \\
\hline 5 & Acc-2593 & & 13 & Acc-3020 & & 21 & Acc-3663 & \\
\hline 6 & Acc- 2730 & & 14 & Acc-3026 & & 22 & Acc-3665 & \\
\hline 7 & Acc-2749 & & 15 & Acc-3556 & & 23 & Acc-3668 & \\
\hline 8 & Acc- 2750 & & 16 & Acc-3563 & & 24 & $\begin{array}{l}\text { BJRI Deshi Pat } \\
\text { (Control) }\end{array}$ & $\begin{array}{l}\text { Breeding } \\
\text { Division, BJRI, } \\
\text { Dhaka. }\end{array}$ \\
\hline
\end{tabular}

augmented design without replication of the tested genotypes except control variety was used for preliminary screening purpose (40, Fig. 1). The control variety was replicated to compare the tested genotypes with it very easily, and the data of replicated control variety were averaged and compared with the values of tested genotypes.

\section{Growing, harvesting, retting, drying of jute fibers and sticks}

The experimental plot size was $3.0 \mathrm{~m}^{2}(3 \mathrm{~m} \times 1 \mathrm{~m})$ for each genotype having 3 lines of $1.0 \mathrm{~m}$ length, plantplant: $10-15 \mathrm{~cm}$ and line- line: $30 \mathrm{~cm}$ distance (Fig. 1). After preparation of lands, jute seeds were sown on 15 March, 2019. Jute plants were grown in farmers' fields at Patuakhali. Agronomic practices like weeding, thinning, fertilization were done properly $(41,42)$. Plants were harvested at 120 days after sowing (15 July); then plants were heaped and allowed to fall off the green leaves for 3 days and finally the green plants or stems were kept under fresh water for 20-25 days and retting was done. Then well retted fibers were collected from outer region of stem and washed in fresh water. The collected fibers were dried using bamboo hanger. After harvesting, 30-35 days (up to mid-August) were required for data collection of jute fiber, stick yield data collection, compilation, analyses and reporting etc.

\section{Data collection and analyses}

The morphological parameters of jute plants (Table 2) were recorded according to the earlier researchers' reports $(26,43-45)$. The plant mortality rate (\%) was observed and recorded at seedling, vegetative and harvesting stages (17). The plant mortality rate was calculated using the formula (Eqn. i).

Plant mortality rate $(\%)=\frac{\text { Total number of plants died }}{\text { Total number of plantsgerminated }} \times 100$
Standard agronomic practices were followed for uniform plant growth (41). Data were analyzed using Microsoft Excel Program (2016) and Statistical Software-Statistix10 (46). Soil salinity was recorded at 15 days interval from sowing to harvesting time using the direct soil pH/EC meter (HI993310).

\section{Results}

\section{Soil salinity, seed germination (\%) and plant mortality (\%)}

During crop growing period, the average soil salinity of the experimental field was 8.0-9.0 $\mathrm{dSm}^{-1}$. Soil salinity was recorded at sowing time (15 March), vegetative stage (80-90 days) and harvesting stage (120 days) respectively (47). Among 24 genotypes of white jute, 22 were successfully germinated and survived; but two genotypes viz. Acc. 3020 and Acc. 3658 were germinated in very low rate and seedlings were died after 20 days of sowing (Fig. 2). It was observed that, the lowest plant or seedling mortality rate $(2.50 \%)$ was found in Acc. 2750 followed by Acc. 1779 (6.24\%), Acc. 1780 (7.50), Acc. 3556 (11.10\%), Acc. 2589 (11.20\%) etc (17, Fig. 5).

\section{Yield and Contributing Characters}

From the descriptive analyses of results, the mean performance for plant height, base diameter, fresh weight with leaves, dry fiber yield and dry stick yield of the studied germplasm were found statistically significant (Table 3).

\section{Plant height}

Plant height significantly contribute to the fiber yield in Jute crop (49). Considering all the genotypes, plant height was ranged from 0.95 to $2.84 \mathrm{~m}$ with a mean of $1.94 \mathrm{~m}$ (Table 3). The highest plant height $(2.84 \mathrm{~m})$ was observed in Acc. 2750 followed by Acc. 2589 (2.76 $\mathrm{m})$ and Acc. 1779 (2.69 m)

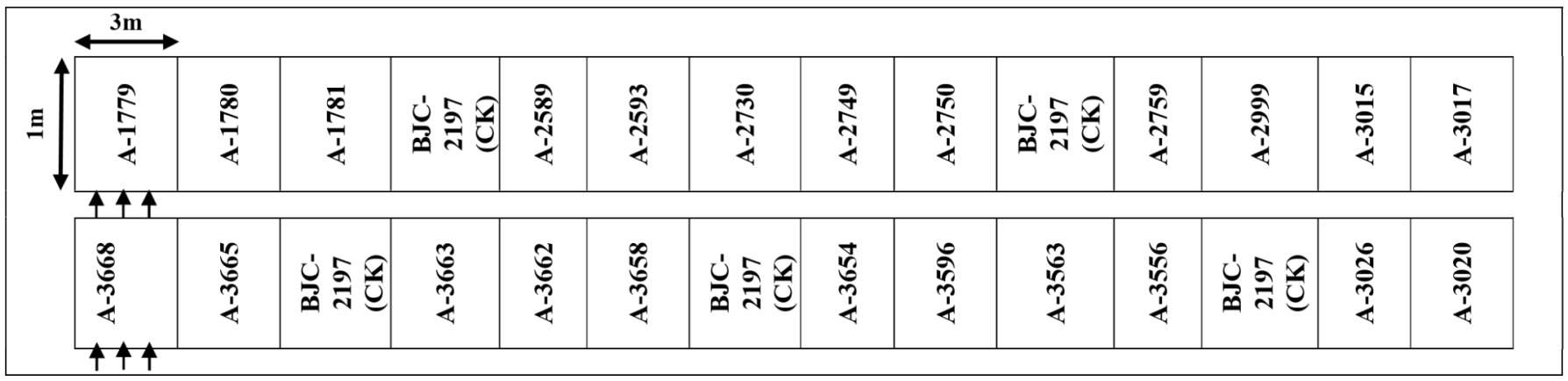

Fig 1. Field layout of the experiment. 
Table 2. Collection method of experimental data

\begin{tabular}{|c|c|c|c|}
\hline $\begin{array}{l}\text { SL. } \\
\text { No. }\end{array}$ & Morphological parameters & $\begin{array}{c}\text { Unit of } \\
\text { measurement }\end{array}$ & Method of collection \\
\hline 1 & Plant height & Meter (m) & $\begin{array}{l}\text { The average stem height of plant (base-apex) was taken from } 10 \text { plants } \\
\text { using measuring tape. }\end{array}$ \\
\hline 2 & Girth or base diameter & Millimeter (mm) & $\begin{array}{l}\text { The average diameter of the plant stem at base was taken from } 10 \\
\text { plants using slide calipers. }\end{array}$ \\
\hline 3 & Green weight of plants & g plant $^{-1}$ & $\begin{array}{l}\text { The average fresh or green weight of the plant was taken from } 10 \\
\text { plants using digital balance or scale. }\end{array}$ \\
\hline 4 & Dry fiber yield & g plant $^{-1}$ & $\begin{array}{l}\text { The average dry fiber yield of the plant was taken from } 10 \text { plants using } \\
\text { digital balance or scale. }\end{array}$ \\
\hline 5 & Dry stick yield & g plant $^{-1}$ & $\begin{array}{l}\text { The average stick yield of the plant was taken from } 10 \text { plants using } \\
\text { digital balance or scale. }\end{array}$ \\
\hline 6 & Soil salinity & $\mathrm{dS} \mathrm{m}^{-1}$ & $\begin{array}{l}\text { Soil salinity levels were recorded using direct } \mathrm{EC} / \mathrm{pH} \text { meter at } 15 \text { days } \\
\text { interval from several locations of plot. The average salinity was } \\
\text { calculated. }\end{array}$ \\
\hline
\end{tabular}

120

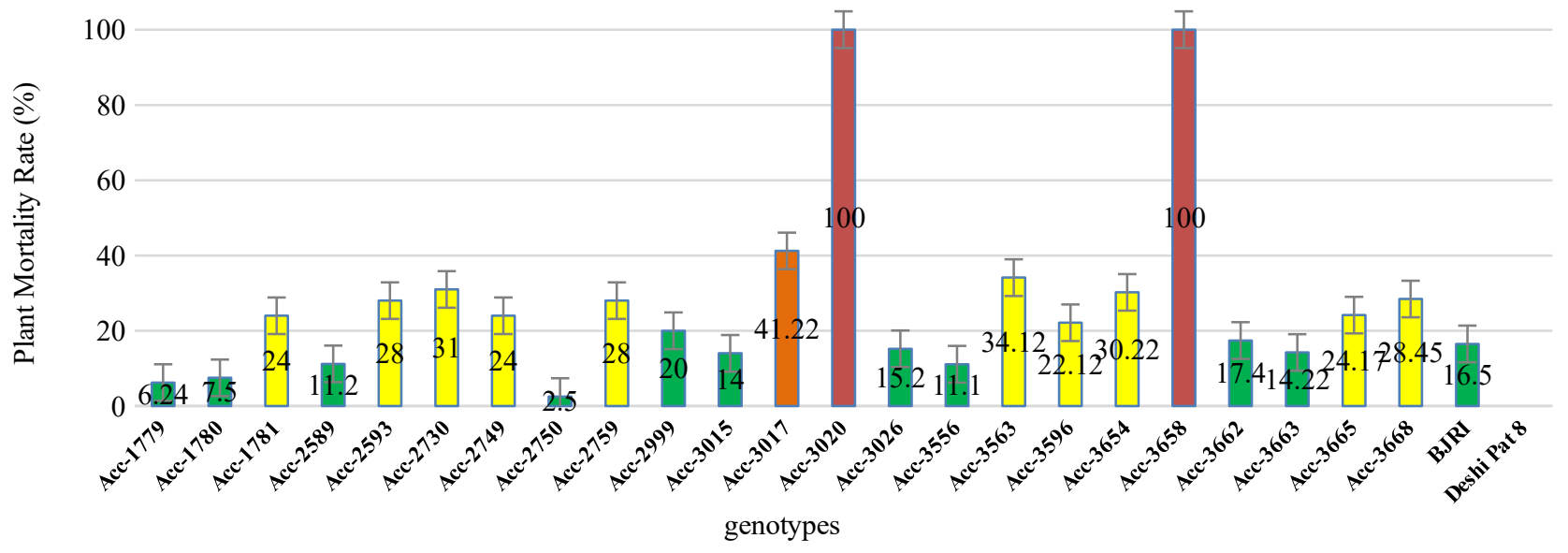

Fig. 2. Mortality percentage of different white jute accessions.

Note: Genotypes with green bar are salt tolerant (plant mortality rate $\leq 20 \%$ ), yellow are moderately salt tolerant (plant mortality rate $<40 \%$ ) and red are susceptible for soil salinity (plant mortality rate $>40 \%)(48)$.

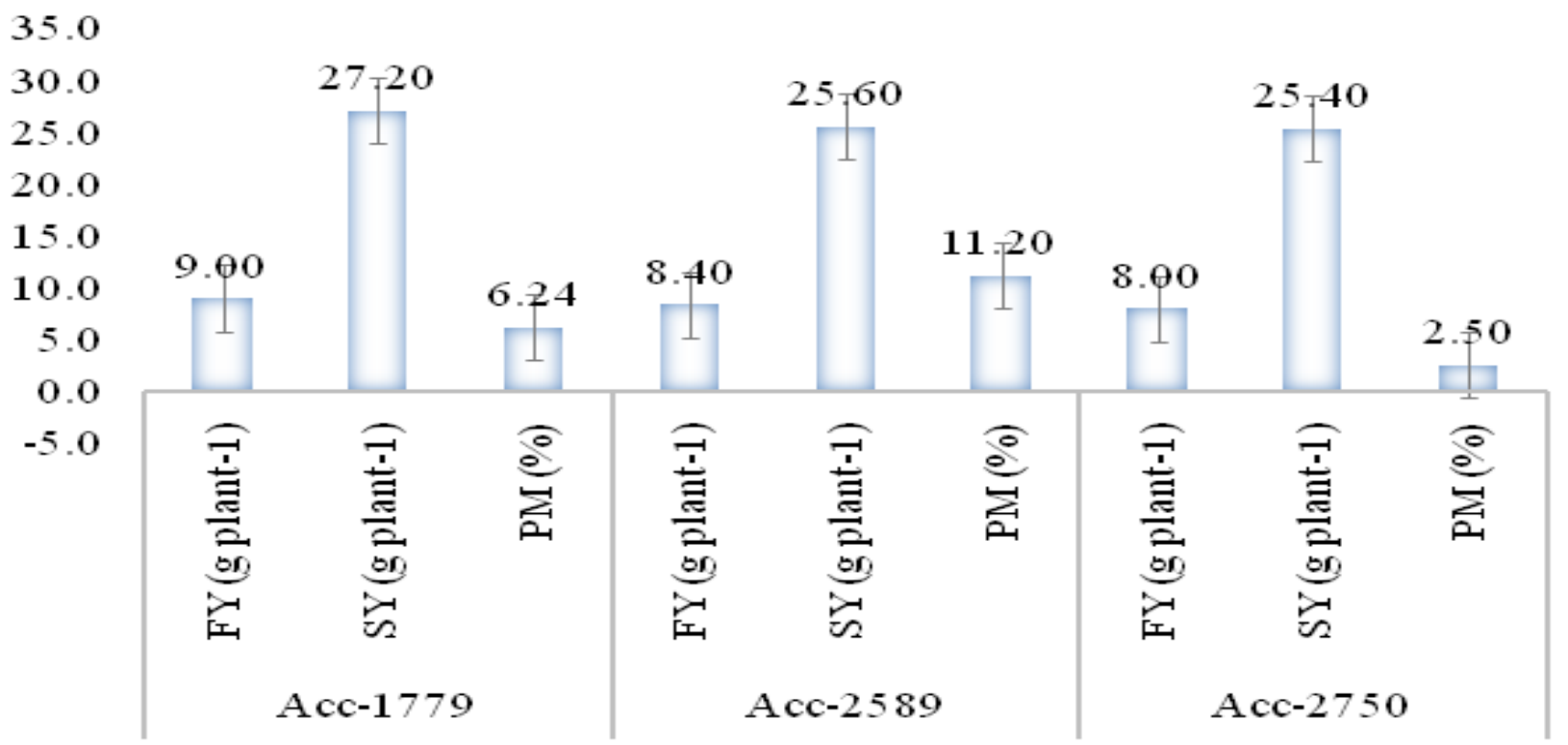

\section{Characters of genotypes}

Fig. 5. Graphical view of fiber yield, stick yield and plant mortality rate of Acc. 1779, Acc. 2589 and Acc. 2750 Note: FY-Fiber yield, SY-Stick yield, PM-Plant mortality. 


\section{Base diameter}

The highest girth or plant base diameter $(20.0 \mathrm{~mm})$ was recorded in Acc. 2589 followed by Acc. 2750 (19.60 mm), Acc. 1779 (19.40 mm), Acc. 2999 (18.80 $\mathrm{mm})$, Acc. $2730(18.20 \mathrm{~mm})$, Acc. $3596(18.20 \mathrm{~mm})$, Acc. 1781 (18.20 mm), Acc. 1780 (18.0 mm) (Table 3). among the five clusters, cluster I and V were larger and each of them consisted of 6 genotypes (25\%). The control variety BJRI Deshi pat-8 was found in cluster I, and the other cluster were consisted of accessions. Intra and inter cluster distances for similar and dissimilar white Jute genotypes were assessed by using ward's

Table 3. Statistical analyses for studied morphological characters of 24 white jute genotypes

\begin{tabular}{|c|c|c|c|c|c|c|}
\hline Sl. No. & Acc./Var. & PH (m) & BD (mm) & $\begin{array}{c}\text { GW } \\
\left(\text { g plant }^{-1}\right)\end{array}$ & $\begin{array}{c}\text { FY } \\
\left(\text { g plant }^{-1}\right)\end{array}$ & $\begin{array}{c}\text { SY } \\
\left.\text { (g plant }^{-1}\right)\end{array}$ \\
\hline 1 & Acc-1779 & 2.69 & 19.40 & 398.00 & 9.00 & 27.20 \\
\hline 2 & Acc-1780 & 2.54 & 18.00 & 238.40 & 7.45 & 19.22 \\
\hline 3 & Acc-1781 & 2.44 & 18.20 & 304.00 & 5.80 & 17.00 \\
\hline 4 & Acc-2589 & 2.76 & 20.00 & 384.00 & 8.40 & 25.60 \\
\hline 5 & Acc-2593 & 2.44 & 17.90 & 186.00 & 7.20 & 19.40 \\
\hline 6 & Acc-2730 & 2.43 & 18.20 & 224.00 & 7.20 & 22.40 \\
\hline 7 & Acc-2749 & 2.10 & 15.40 & 192.00 & 5.80 & 16.60 \\
\hline 8 & Acc- 2750 & 2.84 & 19.60 & 330.00 & 8.00 & 25.40 \\
\hline 9 & Acc-2759 & 2.29 & 17.80 & 198.00 & 6.80 & 22.20 \\
\hline 10 & Acc-2999 & 2.21 & 18.80 & 286.00 & 7.20 & 23.00 \\
\hline 11 & Acc-3015 & 1.76 & 15.61 & 140.00 & 5.20 & 15.40 \\
\hline 12 & Acc-3017 & 1.71 & 16.80 & 154.00 & 3.80 & 15.40 \\
\hline 13 & Acc-3020 & - & - & - & - & - \\
\hline 14 & Acc-3026 & 1.76 & 15.80 & 122.00 & 4.20 & 14.00 \\
\hline 15 & Acc-3556 & 1.72 & 17.40 & 134.00 & 5.60 & 18.40 \\
\hline 16 & Acc-3563 & 1.59 & 16.00 & 48.00 & 2.00 & 4.60 \\
\hline 17 & Acc-3596 & 1.67 & 18.20 & 124.00 & 5.40 & 14.80 \\
\hline 18 & Acc-3654 & 1.42 & 16.00 & 82.00 & 2.40 & 4.60 \\
\hline 19 & Acc-3658 & - & - & - & - & - \\
\hline 20 & Acc-3662 & 1.01 & 13.20 & 70.00 & 1.60 & 4.40 \\
\hline 21 & Acc-3663 & 1.17 & 12.60 & 82.00 & 1.40 & 5.40 \\
\hline 22 & Acc-3665 & 0.97 & 13.50 & 49.00 & 1.44 & 4.42 \\
\hline 23 & Acc-3668 & 0.95 & 13.00 & 34.00 & 1.40 & 4.25 \\
\hline 24 & BJRI Deshi Pat-8 & 2.24 & 16.80 & 356.00 & 7.10 & 17.40 \\
\hline Maximum & & 2.84 & 20.00 & 398.00 & 9.00 & 27.20 \\
\hline Mean & & 1.94 & 16.74 & 187.97 & 5.20 & 15.50 \\
\hline Range & & 1.89 & 7.40 & 364.00 & 7.60 & 22.95 \\
\hline CV (\%) & & 30.71 & 13.05 & 48.52 & 49.66 & 60.52 \\
\hline
\end{tabular}

Note: $P H=$ Plant height $(\mathrm{m}), B D=$ Base diameter $(\mathrm{mm}), G W=$ Green weight with leaves $\left(g\right.$ plant $\left.{ }^{-1}\right), F Y=D r y$ fiber yield $\left(g\right.$ plant $\left.{ }^{-1}\right)$, SY= Dry stick yield $\left(g_{\text {plant }}^{-1}\right), C V(\%)=$ Coefficient of variation in percentage, Comparison among the genotypes for morphological traits based on nonreplicated individual data.

\section{Fresh or green weight}

The more biomass of jute plant indicate the higher yield content of fiber and/or stick (30,50). Among all the genotypes, Acc. 1779 showed higher fresh weight (398.0 gm plant $^{-1}$ ) followed Acc. 2589 (384.0 gm plant $\left.{ }^{1}\right)$, BJRI Deshi Pat 8 (356.0 gm plant $\left.^{-1}\right)$, Acc. 2750 (330.0 gm plant ${ }^{-1}$ ), Acc. 1781 (304.0 gm plant $^{-1}$ ) (Table 3).

\section{Yield components}

Dry fiber yield was ranged from 1.4 to 9.0 gm plant ${ }^{1}$ with a mean of 5.2 gm plant $^{-1}$. The highest fiber yield was recorded in Acc. 1779 (9.0 gm plant $\left.{ }^{-1}\right)$ followed by Acc. 2589 (8.4 gm plant $\left.^{-1}\right)$ and Acc. 2750 (8.0 gm plant $\left.{ }^{1}\right)$. Therefore, Acc. 1779, Acc. 2589, Acc. 2750 would be considered as good for selection and hybridization purposes regarding their fiber yield, stick yield and mortality rate (Fig. 5; Table 3).

\section{Hierarchical Cluster Analysis}

Cluster analysis of morphological traits grouped all genotypes into five major clusters at the genetic distance of 180.0 (Fig. 4) and indicates that 24 white jute genotypes shown remarkable genetic divergence in case of phenotypic traits. It was also observed that, method (Fig. 3, 4). Six genotypes of cluster I (Acc. 1779, Acc. 2589, Acc. 1781, Acc. 2999, Acc. 2750 and BJRI Deshi pat-8) showed higher intra-cluster distance and mean values for all studied morphological characters (Fig. 3, 4). The cluster II and V showed almost similar values at intra level of distance; cluster III gave lowest intracluster distance; while there is no intra-cluster distance in cluster IV. Maximum inter-cluster distance (344.35) was observed between cluster I and IV indicating the higher possibility of variations between the genotypes of these cluster. The two genotypes (Acc. 3020 and Acc. 3658 ) of cluster IV were not germinated in the field and no data were found. These were found susceptible to salt stress.

\section{Discussion}

Soil salinity causes serious damage to the plant root system; hampers the nutrient recycling from soil to plant body and ultimately crop production is drastically decreased (17). A large saline area remains unused due to salinity problem in southern parts of Bangladesh. Hence, development of salinity tolerant white jute variety is a crying need to 
cultivate these saline areas to benefit the farmers' as well as the national economy (51). From this study, the salt tolerant jute genotypes would be used as breeding parents leading to development of high yielding salt tolerant varieties in Bangladesh (52).

According to one study (53), plant height and base diameter are significantly associated with each other directly contributing to fiber yield in jute crops. The increase in plant height and/or base diameter results the increase in fiber and/or stick yield (49). So, the jute genotypes with higher stem height and base diameter would be selected and used as parent(s) in hybridization programme for developing high yielding stress tolerant variety (54).

The fresh weight or green weight of jute plants without leaves contribute to fiber and stick yield

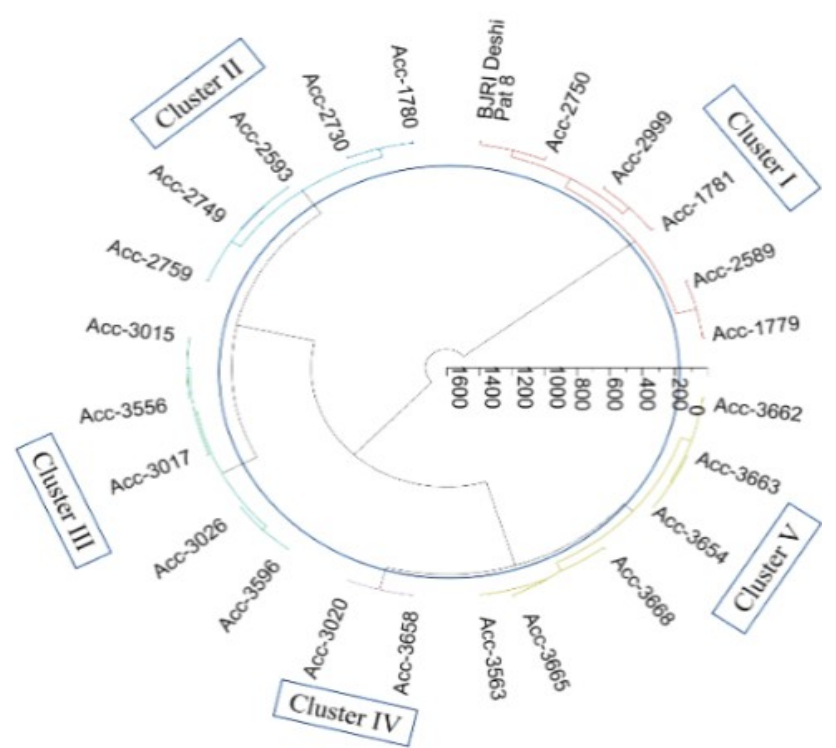

Fig. 3. Euclidean cluster Dendrogram showing the relationships among 24 White Jute genotypes for five morphological characters.

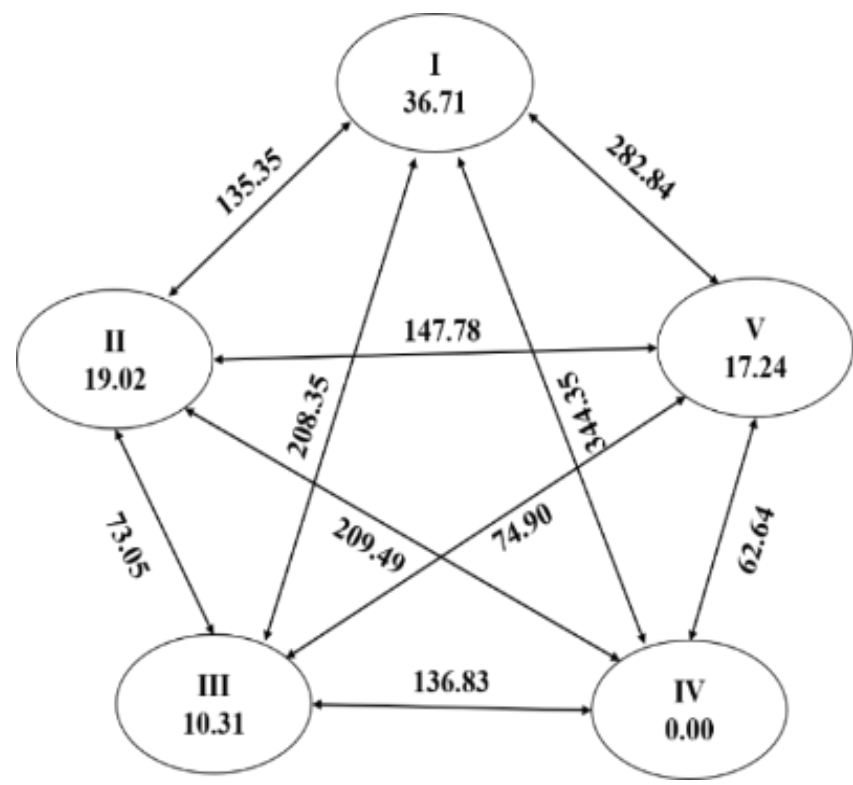

Fig. 4. Average intra and inter cluster distances among five clusters with respective White Jute genotypes.

contents (41). Jute leaves are also important as green manure used in soil (50). Fiber yield is the main criteria of jute crops to consider as a good genotype (55).

Along with stem height and base diameter; fresh weight of jute plants contribute to its fiber and stick yield (56). Plant mortality means the number of plants died in proportion to the number of total plants after germination expressed as percentage (57). Plant population is an important factor contributing the fiber and stick yield in jute crops (41).

The jute genotypes having good germination as well as survivability rate, higher plant height, girth of stem, fiber yield even after growing under salinity stresses would be selected as salinity tolerant genotype; and would be used as breeding materials (49). So, among all the experimental genotypes, Acc. 1779, Acc. 2589, Acc. 2750 were superior for selection and hybridization purpose regarding their fiber yield, stick yield and mortality rate (Fig. 5). White Jute genotypes showed remarkable genetic divergence in case of phenotypic traits (47). The dendrogram tends to group some of the genotypes with similar morphological traits into the same cluster (58).

The genotypes of cluster I showed higher diversity but the cluster II, III, V showed almost similar type diversity. The higher inter cluster distances reveals the presence of high genetic divergence between the clusters, while estimating genetic diversity of jute identical result was reported (59). Selecting the jute genotypes from high inter cluster distances with high mean values for fiber yielding characters will help in developing high heterotypic hybrids and also useful in selecting better recombinants in the segregating generations for higher fiber yield (10). The average inter cluster distances were higher than the average intra cluster distances, which indicates the presence of wide genetic diversity among the genotypes of different clusters than those of same cluster (60). Salinity is a serious abiotic stress to Jute and other crop cultivation at saline regions in the world (61).

So, the three white jute genotypes (Acc. 1779, Acc. 2589, Acc. 2750) from cluster I were superior for selection and hybridization purpose which was corroborated with an earlier study in C. olitorius (47, 61).

\section{Conclusion}

Salinity is a serious abiotic stress to Jute and other crop cultivation at saline regions in the world. There are 23 white jute accessions and one moderately salt tolerant white jute variety were investigated to isolate the salt tolerant accession(s) and to study the morphological performances contributing to fiber yield. The experimental results revealed that the genotypes were varied for the studied traits under salinity stresses. Among all the genotypes, Acc. 1779, Acc. 2589 and Acc. 2750 were relatively more salt tolerant compared to control variety and showed good performances for morphological traits i.e. fiber yield, plant height, base diameter, fresh weight and plant mortality rate etc. which contribute to fiber yield. These genotypes would be considered as good in respect of salinity tolerance and these are need to 
grow again in the area having more salt stressed environment for the confirmation. These good genotypes would be used as breeding materials or parents to transfer or incorporate the genes for respective desired traits in one existing cultivar for salt stress tolerance or higher fiber yield potentialities.

\section{Acknowledgements}

The authors were very much thankful to the Bangladesh Jute Research Institute for giving the opportunity to carry out the investigation. They were grateful to the head of the Breeding Division, BJRI for availing the field and laboratory facilities; and all the colleagues, laboratory assistants for their cordial assistances during the experiment.

\section{Authors' contributions}

NA, RKG, MGM and MMM planned the experiment and NA sanctioned all facilities required. They also helped to set up the experiment. SAJ and IJN were sown the seed materials in field. The morphological and soil salinity data were recorded by MHR, MMM and TS at vegetative phase, and by RKG, MGM and TS at maturity or final harvesting stage of jute plants. Finally, SAJ, MHR and MMM compiled the data, analyzed, reported for presentation. MMM conceptualized the experimental design, experimental set up, article writing, submission and corrections. All authors provided critical feedback and helped to shape the research system.

\section{Conflict of interests}

The authors do not have any conflict of interests to declare.

\section{Funding Source}

This research investigation didn't get any funding source from outside. It was conducted under the core research programme of Bangladesh Jute Research Institute with the successful assistances of the respective personnel of BJRI.

\section{References}

1. Islam MM, Ali MS. Industrial Research Advances of Jute in Bangladesh. International Journal of Agricultural and Biosystems $\quad$ Engineering. 2018;3(1):1-9. http://aascit.org/journal/archive2?journalId=805\&paperId=5820

2. Sarkar D, Kundu A, Saha A, Mondal NA, Sinha MK, Mahapatra BS. First nuclear DNA amounts in diploid $(2 n=2 x=14)$ Corchorus spp. by flow cytometry: genome sizes in the cultivated jute species (C. capsularis L. and C. olitorius L.) are $\sim 300 \%$ smaller than the reported estimate of $1100-1350 \mathrm{Mb}$. Caryologia. https://doi.org/10.1080/00087114.2002.10589776

3. Mahapatra AK, Saha A. Genetic resources of jute and allied fiber crops. In: Karmakar PG, Hazra SK (eds). Jute and allied fiber updates. CRIJAF, Barrackpore, 2008;18-37.

4. Maiti RK. Plant fibres. Bishen Singh Mahendra Pal Sing, Dehra Dun.
https://books.google.com.bd/books/about/Plant_Fibres.html? id=qDJBAAAAYAAJ\&redir_esc=y

5. Kundu A, Topdar N, Sarkar D, Sinha MK, Ghosh A, Banerjee S, Das M, Balyan HS, Mahapatra BS, Gupta PK. Origin of white (Corchorus capsularis L.) and dark (C. olitorius L.) jute: a reevaluation based on nuclear and chloroplast microsatellites. J Plant Biochem Biotechnol. 2013;22:372-81. http://dx.doi.org/10.1007/s13562-012-0165-7

6. Kundu BC. Origin of jute. Indian J Genet Plant Breed. 1951; 11:9599. https://indianjournals.com/Mobile/SearchResult.aspx?query=3

7. Benor S, Demissew S, Hammer K, Blattner FR. Genetic diversity and relationships in Corchorus olitorius (Malvaceae) inferred from molecular and morphological data. Genet Resour Crop Evol. 2012;59:1125-46. http://dx.doi.org/10.1007/s10722-0119748-8

8. Hossain MB, Haque S, Khan H. DNA Fingerprinting of jute germplasm by RAPD. J Biochem Mol Biol. 2002;35:414-19. PMID: 12297002. https://doi.org/10.5483/bmbrep.2002.35.4.414

9. Kar CS, Kundu A, Sarkar D, Sinha MK, Mahapatra BS. Genetic diversity in jute (Corchorus spp) and its utilization: a review. Indian Journal of Agricultural Sciences. 2009;79(8):575-86 https://www.researchgate.net/publication/235666679

10. Mukul, MM. Elucidation of genotypic variability, character association and genetic diversity for stem anatomy of twelve Tossa Jute (Corchorus olitorius L.) Genotypes. Hindawi: BioMed Research International. 2020;9424725. https://doi.org/10.1155/2020/9424725

11. Maity S, Chowdhury S, Datta AK. Jute biology, diversity, cultivation, pest control, fiber production and genetics. In: Lichtfouse E. (eds) Organic Fertilisation, Soil Quality and Human Health. Sustainable Agriculture Reviews. 2012. vol 9. Springer, Dordrecht. https://doi.org/10.1007/978-94-0074113-3_9

12. Basu A, Ghosh M, Meyer R, Powell W, Basak SL, Sen SK. Analysis of genetic diversity in cultivated jute determined by means of SSR markers and AFLP profiling. Crop Sci. 2004;44 678-85. https://doi.org/10.2135/cropsci2004.6780

13. Shrivastava P, Kumar R. Soil salinity: A serious environmental issue and plant growth promoting bacteria as one of the tools for its alleviation. Saudi Journal of Biological Sciences. 2015;22:123-31. http://dx.doi.org/10.1016/j.sjbs.2014.12.001

14. Ghosh RK, Thitaporn Phumichai, Tanee Sreewongchai, Sutkhet Nakasathien, Chalermpol Phumichai. Evaluation of Salt Tolerance of Jute (Corchorus spp.) Genotypes in Hydroponics using Physiological Parameters. Asian Journal of Plant Sciences. https://doi.org/10.3923/ajps.2013.149.158 2013;12:149-58

15. MR Naik, D Barman, RT Maruthi, VR Babu, UK Mandal, DK Kundu, Assessment of salinity tolerance based upon morphophysiological attributes in white jute (Corchorus

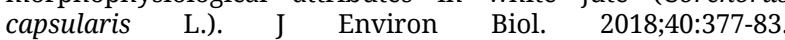
https://doi.org/10.22438/jeb/40/3/MRN-905

16. Alam MZ, Carpenter-Boggs L, Mitra S, Haque MM, Halsey J, Rokonuzzaman M, Saha B, Moniruzzaman M. Effect of salinity intrusion on food crops, livestock and fish species at Kalapara coastal belt in Bangladesh. Journal of Food Quality. 2017; Article ID:2045157. https://doi.org/10.1155/2017/2045157

17. Haque SA. Salinity problems and crop production in coastal region of Bangladesh. Pakistan J Botany. 2006;38(5):1359-65. http://www.pakbs.org/pjbot/PDFs/38(5)/ PJB38(5)1359.pdf

18. Palash W. Salinity in the south west region of Bangladesh and the impact of climate change. 2015. http://www.studentswaterdiplomacy.org/blog/2015/4/8/salinity-in-the-south-westregion-of-bangladesh-and-impact-of-climate-change

19. Huq S, Rabbani G. Adaptation technologies in agriculture; The economics of rice farming technology in climate vulnerable areas of $\quad$ Bangladesh. 2011. https://www.researchgate.net/publication/251572029

20. Hossain ML, Hossain MK, Salam MA, Rubaiyat A. Seasonal variation of soil salinity in coastal areas of Bangladesh. International Journal of Environmental Science, Management and Engineering Research. 2012;1(4):172-78. 
21. Gupta B, Huang B. Mechanism of salinity tolerance in plants: Physiological, biochemical and molecular characterization. International Journal of Genomics. 2014; Article ID 701596. http://dx.doi.org/10.1155/2014/701596

22. SRDI-Soil Research Development Institute. Annual Report on Analyses Soil Collected from Coastal Regions of Bangladesh. 2010. www.srdi.gov.bd

23. Habiba U, Abedin MA, Shaw R, Hassan AWR. Salinity-induced livelihood stress in coastal region of Bangladesh. Community, Environment and Disaster Risk Management. Water Insecurity: A Social Dilemma. 2014;13. https://doi.org/10.1108/S2040-7262(2013)0000013013/full/html

24. Iftekhar MS, Islam MR. Managing mangroves in Bangladesh: a strategy analysis. Journal of Coastal Conservation. 2004;10(1-2):139-46. https://doi.org/10.1652/1400 0350(2004)010[0139:MMIBAS]2.0.CO;2

25. Mahmuduzzaman M, Ahmed ZU, Nuruzzaman AKM, Ahmed FRS. Causes of salinity intrusion in coastal belt of Bangladesh. International Journal of Plant Research. 2014;4(4A):8-13. https://doi.org/10.5923/s.plant.201401.02

26. Khanom A, Chowdhury AK, Mehedi MNH, Mohosina F, Akhter M. Growth and yield performances of salt tolerant jute lines (Corchorus capsularis L.) In coastal area of Bangladesh. Bangladesh J Environ Sci. 2018;35:51-56. https://www.researchgate.net/publication/335444870

27. Rayhan SM, Rahand MA, Amin HA. Effect of planting time and magnesium on the growth and yield of jute seed. Bangladesh Res Publi J. 2008;1(4):303-11.

28. Wang MC, Peng ZY, Xia GM. Proteomic analysis on a high salt tolerance introgression strain of Tricicum aestivum/Thinopyrum ponticum. Proteomics. 2008;8:1470-89. https://doi.org/10.1002/pmic.200700569

29. Ashraf MY, Akhtar K, Hussain F, Iqbal J. Screening of different accession of three potential grass species from Cholistan desert for salt tolerance. Pakistan J Bot. 2006;38:1589-97. http://www.pakbs.org/pjbot/PDFs/38(5)/PJB38(5)1589.pdf

30. Islam MM. Varietal advances of jute, kenaf and mesta crops in Bangladesh: A Review, International Journal of Bioorganic Chemistry. http://dx.doi.org/10.11648/j.ijbc.20190401.15

2019;4(1):24-41.

31. Hossain MM, Abdulla F. Jute production in Bangladesh: A time series analysis. Journal of Mathematics and Statistics. 2015;11(3):93-98. https://doi.org/10.3844/jmssp.2015.93.98

32. Islam MM, Ali MS. Economic importance of jute in Bangladesh: Production, research achievements and diversification. International Journal of Economic Theory and Application. 2017;4(6):45-57. http://article.aascit.org/file/pdf/9180778.pdf

33. Peu NI. The market prospect or export potential of diversified jute products in 2019. http://dspace.bracu.ac.bd/xmlui/handle/10361/11417

34. Akter S, Sadekin MN, Islam N. Jute and jute products of Bangladesh: Contributions and Challenges. Asian Business Review. https://doi.org/10.18034/abr.v10i3.480

35. Mohammadi SA, Prasanna BM. Analysis of genetic diversity in crop plants-salient statistical tools and considerations. Crop Science. 2003;43. https://doi.org/10.2135/cropsci2003.1235

36. Peeters JP, Martinelli JA. Hierarchical cluster analysis as a tool to manage variation in germplasm collections. Theoret Appl Genetics. 1989;78:42-48. https://doi.org/10.1007/BF00299751

37. Ma HY, Wang RJ, Wang XS, H. 2009. Identification and evaluation of salt tolerance of jute germplasm during germination and seedling periods. Journal of Plant Genetic Resources. 10(2):236- 43 .

38. Akram, M, Ashraf MY, Ahmad R, Waraich EA, Iqbal J, Mohsan M. Screening for salt tolerance in maize (Zea mays L.) hybrids at an early seedling stage. Pak J Bot. 2010;20142:141-54. http://www.pakbs.org/pjbot/PDFs/42(1)/PJB42(1)141.pdf

39. Islam MS, Azam MS, Sharmin S, Sajib SA, Alam MM, Reza MS, Ahmed R, Khan H. Improved salt tolerance of jute plants expressing the katE gene from Escherichia coli. Turk J Biol. 2013;37:206-11. http://dx.doi.org/10.3906/biy-1205-52
40. Morsy AR, Fateh HSA. Evaluation and selection of soybean genotypes for yield performance using augmented design Field Crop Research Institute, Egypt. 2016 https://platform.almanhal.com/Files/2/94659.

41. Islam MM, Ali MS. Agronomic research advances in jute crops of Bangladesh. AASCIT Journal of Biology. 2017;3(6):34-46.

42. Chowdhury MAH, Hassan MS. Handbook of agricultural technology. Bangladesh Agricultural Research Council, Dhaka, Bangladesh.

43. Loumerem M, Alercia A. Descriptors for jute (Corchorus olitorius L.). Genet Resour Crop Evol. 2016;63:1103-11. https://doi.org/10.1007/s10722-016-0415-y

44. Zhang L, Ibrahim AK, Niyitanga, Zhang L, Qi J. Jute (Corchorus spp.) Breeding. In: Al-Khayri J, Jain S, Johnson D (eds). Advances in Plant Breeding Strategies: Industrial and Food Crops, Springer, Cham, October. 2019;85-113. https://doi.org/10.1007/978-3-030-23265-8_4

45. Mukul MM, Akter N, Mostofa MG, Rahman MS, Hossain MA-E Roy DC et al. Analyses of variability, Euclidean clustering and principal components for genetic diversity of eight Tossa jute (Corchorus olitorius L.) genotypes. Plant Science Today. 2020;7(4):564-76 https://doi.org/10.14719/pst.2020.7.4.854

46. https://statistix.informer.com/10.0/. Statistix 10 Analytica software. 2020. (Statistix 10.0.0.9)

47. Mukul MM, Akter N, Mostofa MG, Ahmed SSU, Nur IJ, AlMamun M, Rashid MH. Analyses of genetic variability, character association, heritability and genetic advance of Tossa jute (Corchorus olitorius) genotypes for morphology and stem anatomy. American Journal of BioScience. 2020;8(4):99 112. https://doi.org/10.11648/j.ajbio.20200804.12

48. Kakar N, Jumaa SH, Redoña ED, Warburton ML, Reddy KR Evaluating rice for salinity using pot-culture provides a systematic tolerance assessment at the seedling stage. Rice. 2019;12:57. https://doi.org/10.1186/s12284-019-0317-7

49. Bhattarai S, Biswas D, Yong-Bi Fu, Biligetu B. Morphological, Physiological and Genetic Responses to Salt Stress in Alfalfa: A $\begin{array}{ll}\text { Review. } & \text { Agronomy. 2020;10:577. }\end{array}$ https://doi.org/10.3390/agronomy10040577

50. Das K, Biswakarma N, Zhiipao R, Kumar A, Ghasal PC, Pooniya V. Significance and management of green manures. In: Giri B, Varma A (eds). Soil Health. Soil Biology, Cham. Springer. 2020;59. https://doi.org/10.1007/978-3-03044364-1_12

51. Al-Mamun M, Saha CK, Mostofa MG, Miah A, Hossain MZ. Identification of suitable varieties for seed production of jute in non-traditional areas of Bangladesh. Bangladesh J Pl Breed Genet. https://doi.org/10.3329/bjpbg.v30i1.36531

52. Azad MAK, Shah-E-Alam M, Hamid MA, Rafii MY, Malek MA Combining Ability of Pod Yield and Related Traits of Groundnut (Arachis hypogaea L.) under Salinity Stress. The Scientific World Journal. 2014;(1):589586. https://doi.org/10.1155/2014/589586

53. Islam MS, Nasreen A, Begum S, Haque S. Correlated response and path analysis in Tossa jute (Corchorus olitorius L.) Bangladesh Journal of Botany. 2004;33(2):99-102. https://www.researchgate.net/publication/225303660

54. Mukul MM, Akter N, Ahmed SSU et al. Genetic diversity analyses of twelve Tossa jute (Corchorus olitorius L.) genotypes based on variability, heritability and genetic advance for yield and yield attributing morphological traits. International Journal of Plant Breeding and Genetics. 2020;14:9-16. https://doi.org/10.3923/ijpbg.2020.9.16

55. Rasheed A, Malik W, ALI Khan A†, Murtaza N, Qayyum A, Noor E. Genetic evaluation of fiber yield and yield components in fifteen cotton (Gossypium hirsutum) genotypes. International Journal of Agriculture and Biology. Int J Agric Biol. 2009;11:581-85. https://www.fspublishers.org/Issue.php? $\mathrm{y}=2009 \& \mathrm{v} \_$no=11\&categoryID $=106$

56. Islam MR, Islam MM, Nuruzzaman M, Suraiya A. Study of harvest index and genetic variability in white jute (Corchorus capsularis) germplasm. Online J Biol Sci. 2002;2(6):358-60. https://doi.org/10.3923/jbs.2002.358.360 
57. Donohue K, Rubio de Casas R, Burghardt L, Kovach K, Willis CG. Germination, post germination adaptation and species ecological ranges. Annual Review of Ecology, Evolution and Systematics. 2010;41:293-319. https://doi.org/10.1146/annurevecolsys-102209-144715

58. Malek AA, Rafii MY, Afroz MSS, Nath UK, Mondal MMA. Morphological characterization and assessment of genetic variability, character association and divergence in soybean mutants. The Scientific World Journal. 2014;968796. http://dx.doi.org/10.1155/2014/968796

59. Roy A, Bandyopadhyay A, Mahapatra AK, Ghosh SK et al. Evaluation of genetic diversity in jute (Corchorus spp.) using
STMS, ISSR and RAPD markers. Plant Breeding. 2006;125:29297. https://doi.org/10.1111/j.1439-0523.2006.01208.x

60. Rahman S, Miah MAK, Rahman H. Genetic diversity of muskmelon using multivariate technique. Bangladesh J Agril Res. 2016;41(2):273-86. https://banglajol.info/index.php/BJAR/article/view/28230/18798

61. Mukul MM, Ahmed SSU, Akter N, Mostofa MG, Rahman MS Talukder FU. Responses of seed germination, seedling growth under salinity stresses and variability for phenotypic traits in Tossa Jute (Corchorus olitorius L.). Plant Sci Today. 2021;8(1):166-80. https://doi.org/10.14719/pst.2021.8.1.999 